\title{
肥満者における生活習慣と性格上の特徵，および血圧と肥満の 関連について：有効性の高い減量指導法のための基礎的検討
}

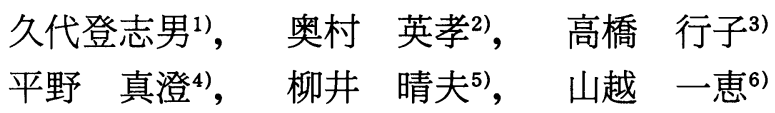

〈緒 言〉肥満は高血圧を含めた動脈硬化疾患の危 険因子であり, 減量は有効な降圧療法であることが認 められている ${ }^{1,2)}$ 。肥満を改善することは, 今後増加す ることが危惧されている動脈硬化性疾患の一次予防を 行なうために重要な課題となっている。しかし, 減量 し, 望ましい体重を維持することは極めて困難である。 その理由として肥満の原因が不明であるとともに, 肥 満者における生活習慣と性格を考慮した個別の対応が 困難な点が挙げられる。本研究は, 都市在住の肥満者 における生活習慣と性格について仮設的な尺度を用い て評価し, 非肥満者と対比することにより肥満者の特 徵と問題点を検討し, さらに肥満度と血圧との関連に ついても調查することを目的に行なわれた。

〈対象と方法〉東京都，および名古屋市に所在する 共同研究施設において健診を受け, 肥満と診断され食 事指導を受けた男性 1,189 例 (46.9 9 土9.1 歳), 女性 376 例(50.5 0.9 歳) (肥満群), および対照として非肥満

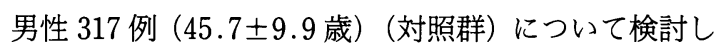
た。生活習慣と性格に関しては調査票により, 職業, 学歴, 家族構成と同居人, 喍好品, 減量の動機, 18 歳 前後の体重, および食行動様式として外食と夜食の頻 度, 食事にかける時間などに関する問とともに, (1) 洋 風の食事に対する嗜好 (2) 糖に対する喍好 (3) 食事 の規則性 (4) 教養型 (5) 社会奉仕 (6) 経済型(節約 型）(7) 妻主導型 (8) 運動意欲 (9) 健康観 (10) 多 愁訴 (11) 情緒不安定 (12) 共感性 (13) 自発性 (14) 持

\section{Behavioral and Personality Characteristics of Obese Subjects and Relation or Blood Pres- sure and Obesity : Consideration of Fffective Measure for Weight Reduction.}

1) 日本大学医学部総合健診センター

2) 愛知県総合保険センター, 総合診断部

${ }^{3)}$ PL 東京健康管理センター

4) ライフ・プランニング・センター

5) 大学入試センター, 研究部評価研究部門

6) 東京八重洲総合健診センター
久性 (15) 自己顕示性の計 15 尺度について評価した。 以上の生活習慣, 性格に関する質問は妥当性, 信頼性 に対する基礎的検討が行なわれ，評価基準として有用 であることが示されているものから採用した ${ }^{3), 4)}$ 。ら に, 健診時の肥満度, および血圧值との関連について 検討した。

〈成績〉肥満群における body mass index (BMI) $26.4 \pm 2 \mathrm{~kg} / \mathrm{m}^{2}$ であり男女差はなく, 対照群 は $21.7 \pm 2 \mathrm{~kg} / \mathrm{m}^{2}$ であった。肥満群と対照群に最も高 い有意差が認められたのは, 飲食のスピードに対する 自己評価であった（図)。特に肥満群男性では $62 \%$ が 速いと感じており,遅いと感じているのは男性の $4 \%$, 女性では $7 \%$ \%みであり, BMI が大きいほど速いと感 じている例が高率であった。また， 40 歳代の肥満群男 性の $61 \%$ \%毎日アルコールを飲むと答えており, 習慣 的飲酒者は肥満群が対照群より有意に多かった。喫煙, 夜食, 外食の回数については両群間に有意差は認めら れなかった。また, 運動意欲, 自発性, 健康感, 多愁 訴の尺度は, 18〜20 歳時の体重と調査時の体重差とは 有意相関を示したが, 調查時 BMI とは相関しなかっ た(表)。肥満の程度を強いと感じている例は, 食事が 不規則で身体関連愁訴が多く, 減量の必要性を強く認 識している例では教養型尺度が高く, 減量に際し食事 以外の生活習慣を変える意志がある例は, 運動意欲, 自発性, 食事の規則性, 教養型, 社会奉仕, 共感性, 持久性尺度の得点が高かった。血圧は肥満群男性が肥 満群女性, および対照群男性より有意に高く, 肥満群 と対照群を併せた全例における BMI と収縮期血圧, および拡張期血圧 $(r=0.217, p<0.0001)$ には有意正 相関が認められ, 体重変化は拡張期血圧と有意相関を 示した。

〈考 案〉肥満群と対照群に最も際だった差が認め られたのは, 飲食のスピードの自己評価であり, 肥満 者では飲食を速いと感じている例が多いことが認めら れた。また, 肥満度に関する認識, 生活習慣, 性格に 関する肥満群における特徴から, 減量指導に際しては, 飲食のスピードと食事の不規則性を改善するととも 


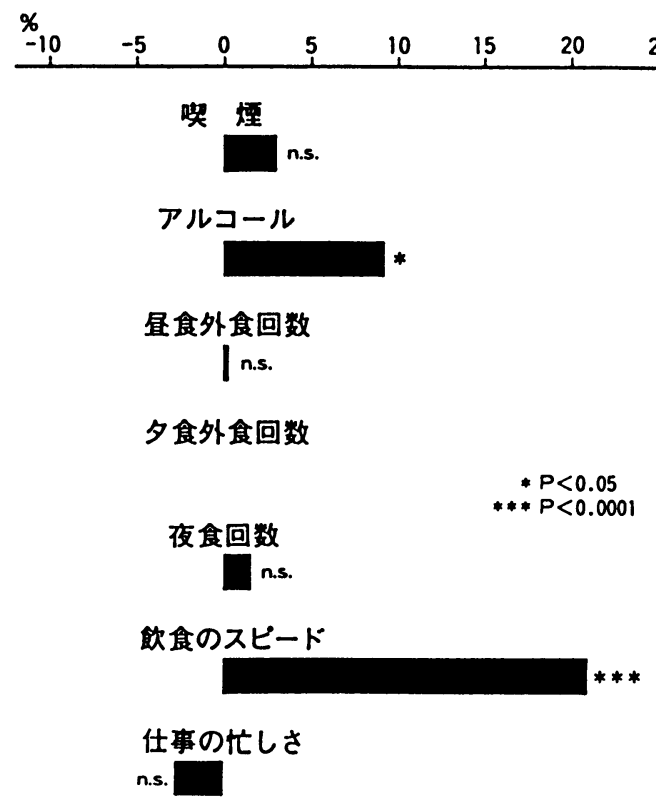

図 肥満群と対照群男性における生活習慣尺度の比較。0\%より左 が対照群の得点が高く, 右が肥満群の得点が高いことを示す。

表 肥満群男性における BMI $\left\{\right.$ 体重 $(\mathrm{kg}) /$ 身長 $\left.\left(\mathrm{cm}^{2}\right)\right\}$ ，および健診 時体重と調査票に記入された 18 歳〜20歳の頃の体重との差と 血圧, および各尺度の得点との相関係数行列。

\begin{tabular}{|c|c|c|}
\hline 变数名 & BM I & (健診時体重) - (18才〜20才頃の体重) \\
\hline 1 収縮期血圧 & $0.127^{\cdots}$ & 0.047 \\
\hline 2 扩張期血圧 & $0.164^{\cdots}$ & $0.102 \cdots$ \\
\hline 3 洋風の食事 & $-0.065^{\circ}$ & $-0.086 \cdots$ \\
\hline 4 榶分 & 0.028 & 0.017 \\
\hline 5 運動意欲 & -0.007 & $-0.092^{\cdots}$ \\
\hline 6 自発性 & -0.048 & $-0.097 \cdots$ \\
\hline 7 情緒不安定 & -0.025 & 0.043 \\
\hline 8 教善型 & -0.023 & -0.015 \\
\hline 9 食事の規則性 & $-0.122 \cdots$ & $-0.107^{\cdots}$ \\
\hline 10 社会奉仕 & 0.028 & -0.043 \\
\hline 11 共感性 & 0.012 & -0.008 \\
\hline 12 健康観 & 0.012 & $0.090^{\cdots}$ \\
\hline 13 節約型 & -0.037 & $-0.071^{\circ}$ \\
\hline 14 持久性 & -0.037 & -0.050 \\
\hline 15 妻主㫫 & 0.016 & -0.003 \\
\hline 16 自己顕示 & 0.004 & -0.013 \\
\hline 17 多愁訴 & -0.005 & $0.097^{\cdots}$ \\
\hline $18 \mathrm{BM} \mathrm{I}$ & 1.000 & $0.518^{\cdots} \cdot$ \\
\hline
\end{tabular}

$\left({ }^{\circ} p<0.05 . \cdots p<0.01, \cdots p<0.001\right)$ 
に, 減量の必要性の認識, および運動意欲, 自発性, 教養型, 社会奉仕, 共感性などについて評価すること が食生活を含めた生活習慣の変容を指導する上で有用 であると考えられた。また, 生活習慣と性格上の特徵 は実測肥満度より体重差の方がより高い相関を示した ことから, 肥満者におけるこれらの特徵は成人期以降 に発症した肥満者に顕著であることが示された。さら に, 血圧值は BMI, 体重変化の両者と相関したことか ら血圧上昇には肥満自体が関連するが，成人以降の体 重増加が増悪因子となっていることが示唆された。
文 献

1）久代登志男, 小池順, 梶原長雄 : 肥満-合併症を伴 った高血圧の治療-臨床医, $15 ： 54-57,1989$

2）久代登志男：軽症高血圧の予後と治療。日本医事 新報, No. 3411，3-14，1989

3）柳井晴夫, 柏木繁男, 国生理枝子：プロマックス 回転法による新性格検査の作成について ( I ), 心 理学研究, $58: 158-165,1987$

4）佐伯圭一郎, 高木廣文, 日野原重明, 他：LPC 式 生活 習慣尺度の作成, 行動計量学, $15: 32-44$, 1988 